\title{
Heat Shock Protein 70 Measurement
}

National Cancer Institute

\section{Source}

National Cancer Institute. Heat Shock Protein 70 Measurement. NCI Thesaurus. Code C147368.

The determination of the amount of heat shock protein 70 present in a sample. 